\title{
Culture As The Foundation of Education In Indonesia
}

\author{
I Ketut Sudarsana ${ }^{1}$, Dian Rianita ${ }^{2}$, Rianti Setyawasih ${ }^{3}$, Akbar Iskandar ${ }^{4}$, Nurhasnah \\ Manurung 5 , Pandu Prabowo Warsodirejo ${ }^{6}$, Dharma Gyta Sari Harahap 7 , Yulia Rizki \\ Ramadhani $^{8}$ \\ \{'iketutsudarsana@uhnsugriwa.ac.id\} \\ ${ }^{1}$ Universitas Hindu Negeri I Gusti Bagus Sugriwa Denpasar, Bali, Indonesia, ${ }^{2}$ Faculty of Administration \\ - Universitas Lancang Kuning, Pekanbaru, Indonesia, ${ }^{3}$ Faculty of Economics; Management Program; \\ Universitas Islam 45 Bekasi, Bekasi, Indonesia, ${ }^{4}$ Informatics Engineering, STMIK AKBA, Makassar, \\ Indonesia, ${ }^{56}$ Faculty of Education and Teaching Training, Universitas Islam Sumatera Utara Medan, \\ Indonesia, ${ }^{7,8}$ Faculty of Education and Teaching Training, Universitas Graha Nusantara \\ Padangsidimpuan, Indonesia
}

\begin{abstract}
Talking about the educational foundation, the educational foundation is necessary in Indonesia, so that our country's ongoing education in a country we had a foundation or a very strong steps because the education in every country is not the same. Education is something that is universal and runs continuously from generation to generation. The effort of humanizing mankind through education is organized in accordance with the views of socio-cultural life of every society. Understanding of the Foundation of education is very important to use in making a decision and appropriate action in education. This is important because the results of education did not immediately seemed, so any decisions and actions taken in education should be tested.
\end{abstract}

Keywords: Culture; Education

\section{Introduction}

The legislation of the Republic of Indonesia Number 20 in 2003 about national education system [1], defines education as a conscious effort and planned to bring about an atmosphere of learning and the learning process so that students developing the potential actively for them to have a religious spiritual strength, self-control, personality, intelligence, morals, as well as the necessary skills themselves, the community, the nation and the State. While the education standards are minimum criteria of the education system in all regions of Indonesian republic's unity state law. Understanding learning in the Sisdiknas ACT is the process of student and teacher interaction of learning resources in a learning environment.

Indonesia is a rich country in culture of each tribes and the Islands. The culture cultivation will be effective provided that both of the formal and nonformal education as well as to preserve and maintain the culture of each region because culture is the character of a nation and State. Educational issues facing the Nations of Indonesia is still the low quality of education and more recently world education in indonesia is still questioning the school curriculum which is about the replacement of the curriculum.

One of the online News Center Tribunnews Friday, January 25, 2013 in its announcement contains the following; in the 2013 curriculum draft, there is no clarity to the position of local languages as subject. Moreover, it had appeared steatment from one of the curriculum 
development team stated that the removal of the language subjects in the curriculum area is reasonable because of this varying lateral community at this time.

From the explanation above, it certainly makes a very loud reactions from the various circles of society, given that to preserve and maintain the local languages, one way is through the learning process in education. Because that's where the generation gain knowledge in a systematic and programmed. Brooks \& Brooks believes that culture-based learning approach can provide opportunities to learners to create meaning and reach an understanding of integrated scientific information acquired, as well as the application of information science in the context of the problems of the cultural communities [2] [3]. Based on the description of the background of the problem, then this simple writings will discuss about culture as the Foundation of education in Indonesia.

\section{Method}

This research includes library research which is a type of qualitative research which generally does not go into the field in searching for data sources. Literature research is a method used in searching data, or a way of in-depth observation of the theme under study to find a 'temporary answer' of the problems found at the beginning before the research is followed up. In other words, library research is a method of searching, collecting and analyzing data sources to be processed and presented in the form of library research reports.

\section{Result and Discussion}

The essential of education is responsibility of member society, nation and state of newer generation for better humanity of life. There are tree kind important education, they are education value and giving its consideration, education guided to society of life, education implementation influenced and supported by environment society [4] [5]. Education could be defined as socialization process which are value socialization, knowledge, attitude, and skill. The purpose of our education comes from various indonesian cultural roots in UU national education system, it's rules number 20 in 2013. It said the purpose of national education is to develop student potential to become a man of faith and piety to God Almighty, precious, healthy, knowledgeable, competent, creative, independent, and become democratic citizen and responsible.

The philosophy of education is perenialism which is centered on the preservation and culture development and progressive education centered on subject development of student to be refined. Perenialism of education philosophy and progressive by looking at the subject of student as part of world citizen, and reminding seriously that citizens are not dictated by alteration but they able to act as nation by providing alternative. On the basis of this, the mission of national education is interpreted as social reconstruction. The study of education purpose is an important thing, by reminding the journey of each institution which is having vission clearly as always beginning from purpose. Likewise Education leads to better life by achieving the purpose if the the purposes are clearly, the next steps could be continued by thinking other set which is supporting purpose achievemeit effectively and efficiently. The important of clear interpreting purpose, until could be easy other understandable set preparation. 
From the explanation above with purpose of education process are to lead become a better life, to achive purpose want to be achieved in education process need support tools, in this case it is curriculum of learning as foundation in learning process at each school. The curriculum in definition of learning plan together by teaching. It means curriculum is much related with planning and goal achievement while teaching lies on the realization or implementation of plan in teaching and learning activities. Curriculum is all experiences, activities and knowledges of student under guiding and responsible of school or teacher [6] [7]. The curriculum definition giving implication on school program which is all student activities could have learning experiences. The activities relating with indoor activities. For the example, in learning \& teaching process (face to face), Skill practicing and etc or outdoor activities such as Pramuka activity, business tour, visitation, commemoration of national and religious holiday and etc.

Curriculum as a foundation in the learning process at schools which containing plans to be achieved in the process of teaching and learning, if it's connected to educational purposes in accordance with Sisdiknas No.20 in 2013 is national education aiming to the potential development of learners in order to become a man of faith and piety to God Almighty, precious, healthy, competent, creative, independent, and become democratic citizen and responsible and refers to a philosophy of education that is perenialisme based on the preservation and development of culture [8] [9]. In development further, it became wide sources including all elements of culture. Human being is a cultured creature, living in a cultural environment, and undertook to create culture, he should learn the culture, to able living in a cultural environment then culture becomes the main source of the content of the curriculum. This includes all cultural disciplines that have been found and developed by expert, custom values, behaviours, objects and etc.

Cultures in Indonesia is very influential on the development of the era from time to time and natural conditions changed which exist in Indonesia. It is suitable in accordance with the opinion of an expert from Indonesia that is Ki Hajar Dewantara, who expose that culture is the result of society's struggle against nature and the time of prosperity that proved and glory of life community in addressing or facing difficulties and obstacles to achieve prosperity, safety and happiness in their life. According to Koentjaraningrat, Culture is a system of ideas and taste, an action as well as produced by man in his community, who made their own by learning. From the explanation above Educational Foundation is a step in an educational process in order to achieve the goal of education by holding with the national educational system aimed at the development of potential learners in order to become a man of faith and piety to God Almighty, precious, healthy, knowledgeable, competent, creative, independent, and become citizens of a democratic, as well as responsible. To require achieving the national education purpose then it needs a supporting tool in order to help learning process implementation effective and efficient, the tool used is a form of curriculum is structured based on the condition in the world of education that is culturally owned by a country in order for output of every educational process which produce graduates corresponding to the purpose of education.

Sumaatmadja stated that the relationship between culture and education not least there are the key words, that education is acculturation, institutionalization, transfer, imparting, explain, justity, and directing. Education and culture has a very strong linkages [3]. Education could not not be separated with culture. The educational process is not possible without a culture it lasts and flourishes. The educational process is not more than as cultural transmission process. In the anthropology's perspective that educational is the transformation of the socio-cultural system from one generation to another in society. Tilaar explained that education is a process 
of aculturation. In other words, education and culture have a relationship that could not be separated. When talking about education, then any culture participated in it [2] [10]. There is no culture without education and educational Praxis have always been in the sphere of culture did so. In the development of a curriculum besides cultural factors, one of the factor that could not be forgotten is learners. In education or teaching, the learning is children. Education or teaching did not give something on the child, but rather growing potential that already exists in children. The child became a source of teaching activities, they became the source of the curriculum. There are three approaches to children as a source of curriculum, namely the needs of students, the development of the students, as well as the interests of students. So, there is left for the curriculum development of the student's needs, the levels development of the students, as well as things that interest students.

\section{Conclusion}

From explanation above, the conclussion can be drawn that the Sisdiknas ACT No. 20 in 2003 defines education as a conscious effort and planned to bring about an atmosphere of learning and the learning process so that students are developing potential actively itself to religious, power spiritual of self-control, personality, intelligence, morals, as well as the necessary skills themselves, society, nation and State in accordance with national standards of education in Indonesia.Curriculum as a tool that is used as a foundation in the world of education it needs to be developed with attention to the Indonesian cultural elements to produce an cultural output insightful that reflects the cultures of indonesia generally and culture of each indonesian region in particular because of culture and education have a very closely conected that cannot be separated. The educational process is not possible without a culture it lasts and flourishes. The educational process is not more than as a cultural transmission process.

\section{References}

[1] W. Sanjaya, Strategi Pembelajaran Berorientasi Standar Proses Pendidikan. 2010.

[2] H. A. R. Tilaar, "Pendidikan, Kebudayaan, dan Masyarakat Madani Indonesia; Strategi Reformasi Pendidikan Nasional," in ketiga, 2002.

[3] N. Sumaatmadja, Pendidikan Pemanusiaan Manusia Manusiawi. Bandung: Alfabeta, 2002

[4] A. H. Gunawan, Sosiologi Pendidikan: Suatu Analisis Sosiologi Tentang Pelbagai Problem Pendidikan. Jakarta: Rineka Cipta, 2000.

[5] P. Suweka, Sugiharta, Oka and I. K. Sudarsana, "Hypnotic Learning Characteristics On Sisya Brahmakunta Community In Denpasar," Vidyottama Sanatana Int. J. Hindu Sci. Relig. Stud., 2017.

[6] J. S. Brubacher, "Konsep dan teori kurikulum dalam dunia pendidikan," Tata McGraw Hill Publ., 1978.

[7] R. Nurmalasari, R. Dian, P. Wati, P. Puspitasari, W. Diana, and N. K. Dewi, "Peran Guru Dalam Implementasi Kurikulum 2013," J. Berk. Progr. Pascasarj. UM Malang, 2016.

[8] I. K. Sudarsana, "Pemikiran Tokoh Pendidikan Dalam Buku Lifelong Learning: Policies, Practices, And Programs (Perspektif Peningkatan Mutu Pendidikan di Indonesia)," J. Penjaminan Mutu, 2016.

[9] B. Manullang, "Grand Desain Pendidikan Karakter Generasi Emas 2045," J. (Pendidikan Karakter), 2013 
[10] K. U. Sukardjo, M, Landasan Pendidikan Konsep dan Aplikasinya. Jakarta: PT Rajagrafindo Persada, 2013. 